\title{
PERENCANAAN ULANG JETTY DI MUARA BATU PUTIH MEULABOH
}

\author{
Indra Riandi' ${ }^{1}$, Muhammad Ikhsan², Astiah Amir $^{3}$ \\ ${ }^{1}$ Jurusan Teknik Sipil, Fakultas Teknik, Universitas Teuku Umar, Meulaboh \\ ${ }^{2 \& 3}$ Dosen Jurusan Teknik Sipil, Fakultas Teknik, Universitas Teuku Umar, Meulaboh \\ Email : indrariandi1993@gmail.com
}

\begin{abstract}
ABSTRAK
Muara Batu Putih terletak di Kecamatan Johan Pahlawan Kabupaten Aceh Barat. Penumpukan sedimen pada jetty sebelumnya di mulut muara menjadi permasalahan pada muara ini. Permasalahan ini dapat ditanggulangi dengan pembangunan ulang konstruksi jetty sebagai pelindung muara dari penumpukan sedimen. Oleh karena itu, tugas akhir ini bertujuan untuk merencanakan ulang konstruksi jetty di Muara Batu Putih. Data yang digunakan dalam perencanaan ini berupa data angin, data bathymetri, data pasang surut, data kapal dan data material. Angin dominan yang terjadi adalah dari arah barat sebesar 16,08\%. Tinggi gelombang rencana dihitung dari karakteristik angin yang terjadi adalah 2,00 $\mathrm{m}$. Berdasarkan analisis sedimen di Muara batu Putih didominasi oleh sedimen sepanjang pantai sebesar 23.740.084,35 33 tahun yang berasal dari arah Barat menuju Barat Laut. Perencanaan dimensi alur muara menggunakan ukuran kapal 30 GT sebagai acuan. Lebar alur muara menggunakan lebar alur hidrolik sungai yaitu $80 \mathrm{~m}$ dan kedalaman alur pelayaran yang digunakan adalah 2,5 m. Konstruksi jetty yang dibangun adalah tipe jetty panjang. panjang jetty sebelah kanan $450 \mathrm{~m}$ dan sebelah kiri $460 \mathrm{~m}$. Jetty direncanakan dari material batu alam. Lapis luar jetty bagian kepala digunakan batu dengan berat $1429,580 \mathrm{~kg} / \mathrm{unit}$ sedangkan bagian lengan adalah 1357,151 kg/unit. Elevasi tinggi rencana jetty adalah $+3,60 \mathrm{~m}$ dan lebar puncak jetty bagian kepala 4,50 m serta bagian lengan 3,00 m.+3,60 m dan lebar puncak jetty bagian kepala 4,50 m serta bagian lengan 3,00 m.
\end{abstract}

Kata kunci: gelombang, angkutansedimen, Jetty

\begin{abstract}
Abstaract
Muara Batu Putih is situated in Johan Pahlawan sub-district of West Aceh District Sediment on the jetty at the mouth of the estuary previously been a problem in this estuary. This problem can be overcome by rebuilding the jetty construction as the protector of estuary sediment buildup. Therefore, this thesis aims to plan the re-construction of the jetty at Muara Batu Putih. The data used in this planning in the form of wind data, the data bathymetry, tide data, ship data and material data. The dominant wind that occurs is from the west amounting to $16.08 \%$. Wave height calculated plan of the characteristics of the wind that occurs is $2.00 \mathrm{~m}$. Based on the analysis of sediments in the estuary White dominated by sedimentary rocks along the coast of $23.740 .084,35 \mathrm{~m} 3$ / year coming from west to Northwest. Planning the mouth of the groove dimensions using the size of the vessel 30 GT as a reference. Groove width wide estuary using a hydraulic flow of the river is $80 \mathrm{~m}$ and the depth of the shipping channel used was $2.5 \mathrm{~m}$. Construction jetty built is a long jetty type. length of $450 \mathrm{~m}$ jetty right side and the left $460 \mathrm{~m}$. Jetty planned from natural stone material. The outer layer is used a stone jetty head weighing $1429.580 \mathrm{~kg} /$ unit while the arm is $1357.151 \mathrm{~kg} / \mathrm{unit}$. High elevation plan is $+3.60 \mathrm{~m}$ jetty and the jetty peak width $4.50 \mathrm{~m}$ head and arm 3,00 $\mathrm{m} .+3,60 \mathrm{~m}$ and the peak width $4.50 \mathrm{~m}$ jetty head and the arm $3.00 \mathrm{~m}$.
\end{abstract}

Keywords: wave, angkutansedimen, Jetty 


\section{PENDAHULUAN}

Muara sungai adalah bagian hilir dari sungai yang berhubungan dengan laut. Muara sungai berfungsi sebagai pengeluaran atau pembuangan debit sungai, terutama pada waktu banjir, ke laut. Sungai-sungai yang bermuara pada pantai berpasir dengan gelombang cukup besar sering mengalami penyumbatan muara oleh endapan pasir. Karena pengaruh gelombang dan angin, endapan pasir terbentuk di muara. Transpor sedimen sepanjang pantai juga sangat berpengaruh terhadap pembentukan endapan tersebut. Pasir yang melintas di depan muara akan terdorong oleh gelombang masuk ke muara dan kemudian diendapkan. Endapan yang sangat besar dapat menyebabkan tersumbatnya muara sungai. Penutupan muara tersebut dapat menyebabkan terjadinya banjir di daerah sebelah hulu muara. Padamusim penghujan air banjir dapat mengerosi endapansedimen sehingga sedikit demi sedikit muara sungai dapat terbuka kembali. Selama proses penutupan dan pembukaan kembali tersebut biasanya disertai dengan proses membeloknya muara sungai dalam arah yang sama dengan arah transpor sedimen sepanjang pantai. Jetty dapat digunakan untuk menanggulangi masalah tersebut. Mengingat fungsinya untuk alur pelayaran dan penanggulangan banjir, maka dapat digunakan salah satu dari bangunan berikut, yaitu jetty panjang, jetty sedang dan jetty pendek.

Saat ini, muara Batu Putih mengalami sedimentasi yang menyebabkan muara tidak berfungsi lagi. Laju sedimentasi yang tinggi ialah yang menyebabkan volume pendangkalan yang tinggi dalam kurun waktu yang tidak lama. Muara yang dilengkapi dengan konstruksi jetty pada pembangunan sebelumnya telah tertutup dengan sedimen. Jetty yang di pakai pada perencanaan sebelumnya yaitu jetty pendek.

Berdasarkan latar belakang yang telah diuraikan, maka perumusan masalahnya adalah bagaimana laju sedimentasi pada jetty sebelumnya ,b konfigurasi ulang struktur jetty yang efektif. Tujuan dari tugas akhir ini adalah Untuk mengetahui laju sedimentasi pada jetty eksisting. Dan Untuk mengetahui konfigurasi ulang struktur jetty yang efektif.

\section{Lebar puncak jetty}

Menurut Triatmodjo (1999), lebar puncak jetty tergantung pada limpasan yang diijinkan. Pada kondisi limpasan diijinkan, lebar minimum adalah sama dengan lebar tiga butir batu yang disusun berdampingan $(n=3)$. Selain batasan tersebut, lebar puncak harus cukup lebar untuk keperluan operasi peralatan pada saat pelaksanaan dan perawatan jetty.Lebar puncak dapat dihitung dengan rumus berikut:

$B=n k_{\Delta}\left[\frac{W}{\gamma_{r}}\right]^{1 / 3} \ldots \ldots . . . .$.

dimana:

$B \quad=$ lebar puncak $(\mathrm{m})$;

$n \quad=$ jumlah butir batu;

$k_{\Delta} \quad=$ koefisien lapis yang diberikan dalam Tabel

2.2 ;

$W \quad=$ berat unit batu (ton/unit);

$\gamma_{r}=$ berat jenis batu $\left(\operatorname{ton} / \mathrm{m}^{3}\right)$.

Tabel 1 Koefisien Lapis dan Porositas

\begin{tabular}{|c|c|c|c|c|}
\hline Batu Pelindung & $\mathbf{n}$ & Penempatan & $\begin{array}{c}\text { Koef.Lapis } \\
(R \Delta)\end{array}$ & $\begin{array}{c}\text { Porositas } P \\
(\%)\end{array}$ \\
\hline Batu alam (ha1us) & 2 & random (acak) & 1,02 & 38 \\
\hline Batu alam (kasar) & 2 & random (acak) & 1,15 & 37 \\
\hline Batu alam (kasar) & $>3$ & random (acak) & 1,10 & 40 \\
\hline Kubus & 2 & random (acak) & 1,10 & 47 \\
\hline Tetrapod & 2 & random (acak) & 1,04 & 50 \\
\hline Quadripod & 2 & random (acak) & 0.95 & 49 \\
\hline Hexapod & 2 & random (acak) & 1,15 & 47 \\
\hline Tribard & 2 & random (acak) & 1,02 & 54 \\
\hline Dolos & 2 & random (acak) & 1,00 & 63 \\
\hline Tribar & 1 & seragam & 1.13 & 47 \\
\hline Batu alam & & random (acak) & & 37 \\
\hline
\end{tabular}

Sumber : Triatmodjo, 1999. 
Tebal dan jumlah butir batu lapis pelindung

Menurut Triatmodjo (1999), tebal dan jumlah butir batu lapis pelindung dapat dihitung dengan rumus berikut:

$$
\begin{array}{ll}
t & =n k_{\Delta}\left[\frac{W}{\gamma_{r}}\right]^{1 / 3} \ldots \ldots \ldots \ldots \ldots \ldots . . . . . . . . .
\end{array}
$$

dimana:

$t \quad=$ tebal lapis (m);

$n \quad=$ jumlah lapis batu dalam lapis;

$k_{\Delta} \quad=$ koefisien lapis;

$A \quad=$ luas permukaan $\left(\mathrm{m}^{2}\right)$;

$P \quad=$ porositas rerata dari lapis pelindung

$W \quad=$ berat butir batu (ton/unit);

$\gamma_{r} \quad=$ berat jenis batu $\left(\operatorname{ton} / \mathrm{m}^{3}\right)$;

$N \quad=$ jumlah butir batu untuk satu satuan luas permukaan.

\section{Stabilitas batu lapis}

Menurut Triatmodjo (1999), di dalam perencanaan jetty ditentukan berat batu lapis yang terdiri dari lapis luar, lapis kedua, dan lapis ketiga atau lapis inti. Berat butir lapis luar dapat dihitung dengan menggunakan rumus Hudson sebagi berikut :

$$
\begin{aligned}
& W=\frac{\gamma_{r} H^{3}}{K_{D}\left(S_{r}-1\right)^{3} \cot \theta} . \\
& S_{r}=\gamma_{r} / \gamma_{a}
\end{aligned}
$$

dimana:

$\gamma_{r} \quad=$ berat jenis batu $\left(\mathrm{ton} / \mathrm{m}^{3}\right)$;

$\gamma_{a}=$ berat jenis air laut $\left(\right.$ ton $\left./ \mathrm{m}^{3}\right)$;

$\theta \quad=$ sudut kemiringan sisi jetty;

$K_{D} \quad$ = koefisien stabilitas tergantung pada bentuk batu

Untuk terat batu lapis kedua dapat ditentukan dengan rumus Hudson Jackson sebagai berikut:

$$
W_{2} \quad=\frac{W}{10} \text {. }
$$

Untuk berat batu lapis ketiga dapat ditentukan dengan rumus Hudson Jackson sebagai berikut:

$W_{3}=\frac{W}{200}$

\section{Stabilitas kaki jetty}

Menurut Triatmodjo (1999), stabilitas kaki jetty perlu untuk diperhitungkan dikarenakan erosi yang ditimbulkan oleh gelombang mempengaruhi kestabilan konstruksi jetty. Perhitungan berat butir pelindung kaki didasarkan pada perencanaan bangunannya.

$$
\begin{aligned}
W & =\frac{\gamma_{r} H^{3}}{N_{S}\left(S_{r}-1\right)^{3}} \\
S_{r} & =\gamma_{r} / \gamma_{a} \ldots . .
\end{aligned}
$$

dimana:

$W \quad=$ berat rata-rata butir batu (ton);

$\gamma_{r}=$ berat jenis batu $\left(\mathrm{ton} / \mathrm{m}^{3}\right)$;

$H \quad=$ tinggi gelombang rencana $(\mathrm{m})$;

$S_{r} \quad$ = perbandingan antara berat jenis batudengan berat jenis air laut;

$N_{s} \quad$ = angka stabilitas rencana untukPelindung kaki bangunan; 
$\gamma_{a}=$ berat jenis air laut $\left(\mathrm{ton} / \mathrm{m}^{3}\right)$.

\section{METODOLOGI PENELITIAN}

\subsection{Pengumpulan Data}

\subsubsection{Data angin}

Data angin yang digunakan adalah data angin maksimum diperlukan untuk memprediksi tinggi dan periode gelombang, yaitu data angin yang lebih besar dari 10 Knot. Data angin maksimum diplot dalam tabel berdasarkan persentase dan kecepatan angin. Kecepatan angin dibagi dalam enam kelompok angin yang besarannya berkisar dari 0 - 31 Knot.

\subsubsection{Data Topografi dan Bathymetri}

Data topografi merupakan data elevasi di kawasan pantai Batu Putih. Data bathymetri merupakan data kedalaman muara dan laut kawasan Batu Putih yaitu sejauh $2 \mathrm{~km}$ dari muara ke arah laut dan $4 \mathrm{~km}$ sepanjang garis pantai. Data ini akan dipergunakan untuk penentuan letak konstruksi jetty.

\subsubsection{Data Pasang Surut}

Data ini merupakan fluktuasi muka air laut dimana muka air mencapai ketinggian maksimum saat terjadi pasang dan ketinggian minimum saat terjadi surut. Pasang surut yang terjadi pada pantai Batu Putih adalah tipe pasang surut harian ganda, yaitu dalam satu hari terjadi dua kali pasang dan dua kali surut dengan tinggi yang hampir sama.

\subsubsection{Data Material}

Data material diperlukan untuk mengetahui jenis material yang akan digunakan dalam perencanaan konstruksi jetty ini. Batu alam adalah material utama yang digunakan dalam Perencanaan ini. Dalam perencanaan ini data material yang diperlukan berupa berat jenis dari batu alam tersebut berupa 2,65 ton $/$ meter $^{3}$.

\subsubsection{Data Kapal}

Data kapal diperlukan untuk menentukan kedalaman minimum alur pelayaran dan lebar minimum alar pelayaran. Ukuran kapal yang digunakan untuk perencanaan adalah kapal dengan ukuran maksimum yang melewati Muara Lambada Lhok yaitu kapal motor ukuran 30 GT. Dimensi kapal motor 30 GT adalah panjang $25 \mathrm{~m}$, lebar $5 \mathrm{~m}$ dan draf 1,5 $\mathrm{m}$.

\section{HASIL DAN PEMBAHASAN}

\subsection{Hasil}

\subsubsection{Analisis Iklim Kelautan}

Data angin maksimum diplot dalam tabel berdasarkan persentase dan kecepatan angin. Kecepatan angin dibagi dalam enam kelompok angin yang besarannya berkisar dari 0- 31 Knot. Data kecepatan angin yang telah dianalisis dalam bentuk persentase kemudian diplot dalam bentuk mawar angin seperti pada Gambar 1. Distribusi kejadiaan angin maksimum terlihat pada Tabel 2. 
Tabel 2 Kejadian angin maksimum di Stasiun Meteorologi Cut Nyak Dhien Nagan Raya Tahun 2005-2014.

\begin{tabular}{|c|c|c|c|c|c|c|}
\hline $\begin{array}{c}\text { Arah/Kec } \\
\text { (Knot) }\end{array}$ & $0-10$ (Knot) & $\begin{array}{l}10-14 \\
\text { (Knot) }\end{array}$ & $\begin{array}{l}14-18 \\
\text { (Knot) }\end{array}$ & $\begin{array}{l}18-22 \\
\text { (Knot) }\end{array}$ & $\begin{array}{c}>22 \\
\text { (Knot) }\end{array}$ & Total $(\%)$ \\
\hline $\mathrm{T}$ & \multirow{8}{*}{40,51} & 2,78 & 2,51 & 0,93 & 0,23 & 6,45 \\
\hline TG & & 1,35 & 0,84 & 0,51 & 0,27 & 2,97 \\
\hline $\mathrm{S}$ & & 1,29 & 0,84 & 0,51 & 0,7 & 3,34 \\
\hline $\mathrm{BD}$ & & 6,14 & 6,09 & 2,55 & 0,63 & 15,41 \\
\hline $\mathrm{B}$ & & 7,46 & 4,3 & 2,61 & 1,71 & 16,08 \\
\hline $\mathrm{BL}$ & & 2,04 & 1,2 & 0,44 & 0,23 & 3,91 \\
\hline $\mathrm{U}$ & & 1,33 & 0,32 & 0,08 & 0,08 & 1,81 \\
\hline TL & & 4,55 & 2,51 & 0,61 & 0,11 & 7,78 \\
\hline
\end{tabular}

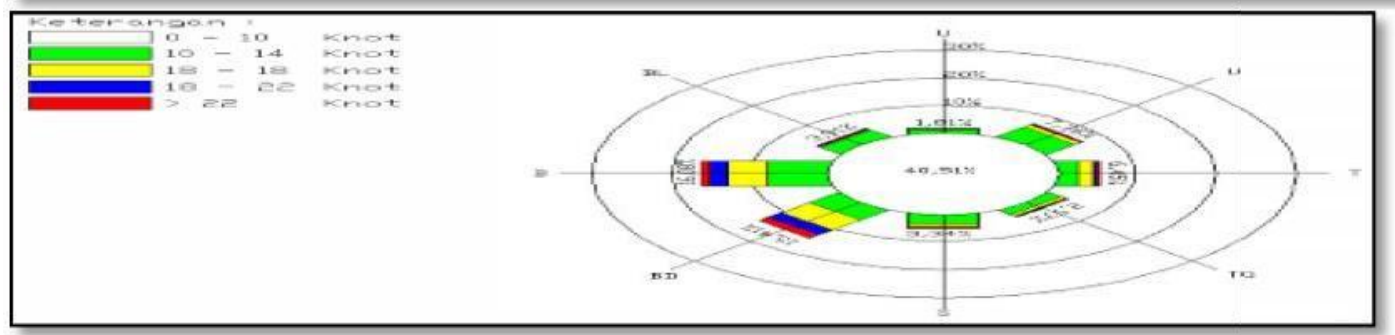

Gambar 4.1 : Mawar Angin Kejadian Maksimum untuk Station Cut Nyak Dhien Nagan raya 2005-2014

\section{A. Peramalan gelombang}

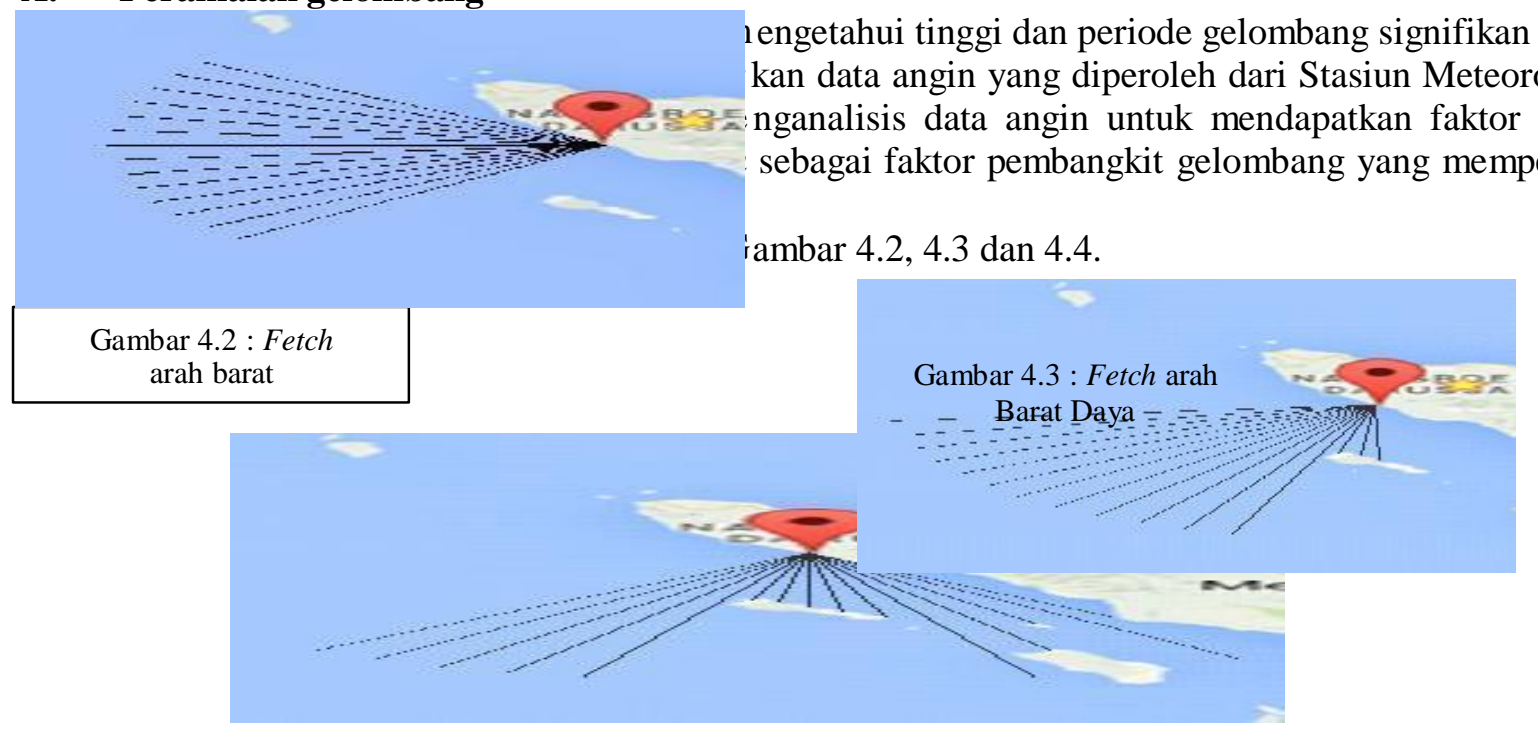

Gambar 4.4 : Fetch arah Selatan 
Arah angin dominan adalah dari sebelah Barat dengan persetase sebesar 16,08\%sedangkan arah angin minimum adalah $1,81 \%$ dari arah Utara. Posisi pantai adalah $35^{\circ}$ dari arah Barat. Berdasarkan kondisi tersebut maka angin yang mengakibatkan terjadinya gelombang diperkirakan berasal arah Barat, arah Barat Daya dan arah Selatan. Dalam presentasinya dapat dilihat dalam pada tabel 4.2.

Tabel 4.2 Nilai Fetch Efektif

\begin{tabular}{|c|c|c|c|c|c|c|c|}
\hline$\alpha=$ & $\cos \alpha=$ & $\begin{array}{c}\text { E ( }(\mathrm{km}) \\
x i\end{array}$ & $\begin{array}{c}\text { BD }(\mathrm{km}) \\
\mathrm{xi}\end{array}$ & $\begin{array}{c}S(\operatorname{lrm}) \\
x i\end{array}$ & $\begin{array}{c}E(\lim ) \\
x i \cos \alpha=\end{array}$ & $\begin{array}{l}\text { PD }(\mathrm{km}) \\
x i \cos \alpha=\end{array}$ & $\begin{array}{l}S(1 \mathrm{~km}) \\
x i \cos \alpha=\end{array}$ \\
\hline 42 & 0,743 & 12,58 & 500,00 & 500,00 & 9,349 & 371,572 & 371,572 \\
\hline $\begin{array}{l}36 \\
30\end{array}$ & $\begin{array}{l}0,809 \\
0.866\end{array}$ & $\begin{array}{l}500,00 \\
500,00\end{array}$ & $\begin{array}{l}500,00 \\
500,00\end{array}$ & $\begin{array}{l}500,00 \\
500,00\end{array}$ & $\begin{array}{l}404,508 \\
433,013\end{array}$ & $\begin{array}{l}404,508 \\
433,013\end{array}$ & 404,508 \\
\hline 24 & 0.914 & 500,00 & 500,00 & 500,00 & 456.773 & 456.773 & 456.773 \\
\hline 18 & 0.951 & 500,00 & 500,00 & 500,00 & 475.578 & 475,578 & 475.578 \\
\hline 12 & 0,978 & 500,00 & 500,00 & 130,06 & 489,074 & 489,074 & 136,902 \\
\hline$G$ & 0,995 & 500,00 & 500,00 & 145,01 & 497,261 & 497,261 & 144,216 \\
\hline 0 & 1,000 & 500,00 & 500,00 & 158,65 & 500,000 & 500,000 & 158,650 \\
\hline 6 & 0,995 & 500,00 & 500,00 & 171,14 & 497,261 & 497,261 & 170,202 \\
\hline 12 & 0,978 & 500,00 & 500,00 & 190,54 & 489,074 & 489,074 & 186,376 \\
\hline 18 & 0.951 & 500,00 & 500,00 & 500,00 & 475,528 & 475.528 & 475.528 \\
\hline 2.4 & 0,914 & 500,00 & 500,00 & 325,21 & 456.773 & 456.773 & 297,094 \\
\hline 30 & 0,866 & 500,00 & 142,75 & 230,29 & 433,013 & 123,625 & 207,231 \\
\hline 36 & 0,809 & 500,00 & 140,63 & 500,00 & 404,503 & 113,772 & 404,503 \\
\hline 42 & 0,743 & 500,00 & 151,13 & 258,58 & 371,572 & 112,311 & 192,152 \\
\hline$\Sigma$ & 13,511 & & & & 6393,235 & 5896,074 & 4514,265 \\
\hline Feff & & & & & 473,190 & 436,393 & 334,120 \\
\hline
\end{tabular}

\section{B. Analisis gelombang rencana}

Pada perencanaan bangunan pantai akan ada gaya-gaya gelombang yang bekerja pada bangunan tersebut, dan gaya-gaya tersebut harus mampu ditahan oleh bangunan pantai yang direncanakan. Perhitungan ini didasarkan pada kondisi ekstrim, yang mana pada kondisi tersebut bangunan harus tetap aman. Tipe perubahan bentuk gelombang dalam perencanaan konstruksi jetty ini adalah shoaling, refraksi dan gelombang pecah.

\section{a. $\quad$ Periode ulang gelombang}

Periode ulang yang dihitung adalah periode ulang 2, 5, 10, 25, 50, dan 100 tahunan. Rekapitulasi Periode ulang tahunan dapat dilihat pada Tabel 4.3 dan rekapitulasi periode ulang tahunan yang telah direduksi $75 \%$ dapat dilihat pada Tabel 4.4.

Tabel 4.3 Periode ulang tinggi gelombang

\begin{tabular}{|c|c|c|c|c|c|c|}
\hline \multirow{2}{*}{$\begin{array}{c}\text { Periode Ulang } \\
\text { (tahun) }\end{array}$} & \multicolumn{2}{|c|}{ Barat } & \multicolumn{2}{|c|}{ Barat Daya } & \multicolumn{2}{|c|}{ Selatan } \\
\hline & $\mathrm{H}(\mathrm{m})$ & T (dtk) & $\mathrm{H}(\mathrm{m})$ & I (dtk) & $\mathrm{H}(\mathrm{m})$ & $T(\mathrm{dtt})$ \\
\hline 2 & 3,02 & 4,608 & 2,837 & 4,492 & 2,470 & 4,333 \\
\hline 5 & 4,31 & 5,610 & 4,195 & 5,551 & 3,232 & 5,056 \\
\hline 10 & 5,17 & 6,273 & 5,094 & 6,252 & 3,737 & 5,534 \\
\hline 25 & 6,25 & 7,112 & 6,230 & 7,138 & 4,374 & 6,139 \\
\hline 50 & 7,06 & 7,734 & 7,072 & 7,795 & 4,847 & $6,58 \$$ \\
\hline 100 & 7,85 & 8,351 & 7,909 & 8,447 & 5,317 & $7,03 \frac{3}{3}$ \\
\hline
\end{tabular}

Tabel 4.4 Periode ulang tinggi gelombang yang telah direduksi $75 \%$

\begin{tabular}{|c|c|c|c|c|c|c|}
\hline \multirow{2}{*}{$\begin{array}{c}\text { Periode Ulang } \\
\text { (tahun) }\end{array}$} & \multicolumn{2}{|c|}{ Barat } & \multicolumn{2}{c|}{ Timur Laut } & \multicolumn{2}{c|}{ Selatan } \\
\cline { 2 - 7 } & $\mathrm{H} \mathrm{(m)}$ & $\mathrm{T}(\mathrm{dtk})$ & $\mathrm{H}(\mathrm{m})$ & $\mathrm{T}(\mathrm{dtk})$ & $\mathrm{H}(\mathrm{m})$ & $\mathrm{T}(\mathrm{dt})$ \\
\hline 2 & 2,26 & 3,46 & 2,13 & 3,37 & 1,85 & 3,25 \\
\hline 5 & 3,23 & 4,21 & 3,15 & 4,16 & 2,42 & 3,79 \\
\hline 10 & 3,88 & 4,71 & 3,82 & 4,69 & 2,80 & 4,15 \\
\hline 50 & 4,69 & 5,33 & 4,67 & 5,35 & 3,28 & 4,69 \\
\hline 100 & 5,29 & 5,80 & 5,30 & 5,85 & 3,64 & 4,9, \\
\hline
\end{tabular}

\section{b. Gelombang rencana}

Penentuan tinggi gelombang pada lokasi perencanaan diperoleh melalui analisa deformasi gelombang. Parameter deformasi yang dihitung adalah shoaling $\left(K_{s}\right)$, dan refraksi $\left(K_{r}\right)$. Perhitungan dilakukan berdasarkan arah datang gelombang yaitu Barat dengan sudut gelombang $35^{\circ}$ arah pantai, arah Barat Daya dengan sudut gelombang $82^{\circ}$ dan arah Selatan dengan sudut gelombang $54^{\circ}$. Berdasarkan hasil 
perhitungan untuk memperoleh nilai $K_{s}, K_{r}$ dantinggi gelombang $(\mathrm{H})$ pada kedalaman $1 \mathrm{~m}$ dari arah gelombang Barat, Barat Daya dan Selatan dapat dilihat pada Tabel 4.5.Tabel 4.5 Perhitungan Tinggi Gelombang Lokasi Arah Barat

\begin{tabular}{|c|c|c|c|c|c|c|c|c|c|c|}
\hline $\mathrm{cm}$ & d/Lo & $d / L$ & $n$ & L & c & $\sin \alpha$ & $\alpha$ & $\mathrm{Kr}$ & $\mathrm{Ks}$ & $H$ \\
\hline 28.5 & 0.627 & 0,62736 & 0,5030 & 44,63 & 8,368 & 0,9895 & 81,700 & 0,98188 & 0,99740 & 4,59 \\
\hline 25.0 & 0,560 & 0,56097 & 0,50610 & 44,57 & 8,355 & 0,9881 & 80,999 & 0,94316 & 0,99506 & 4,40 \\
\hline 22.9 & 0,493 & 0,49496 & 0,51240 & 44,45 & 8,333 & 0,9855 & 80,390 & 0,91305 & 0,99024 & 4,24 \\
\hline 19,6 & 0.425 & 0,42890 & 0,52460 & 44,30 & 8,305 & 0,9822 & 78,950 & 0,85213 & 0.98029 & 3.92 \\
\hline 16.5 & 0,358 & 0,36534 & 0,54660 & 43,79 & 8,211 & 0,9710 & 75,640 & 0,74910 & 0,96588 & 3,39 \\
\hline 13.9 & 0,291 & 0,30404 & 0,5838 & 42,76 & 8,016 & 0,9480 & 71,210 & 0,65733 & 0,94587 & 2,92 \\
\hline 10,0 & 0,224 & 0,24548 & 0,6414 & 40,74 & 7,637 & 0,9032 & 64,530 & 0,56888 & 0.92451 & 2,47 \\
\hline 7.9 & 0,157 & 0,18914 & 0,7226 & 37.01 & 6,939 & 0,8205 & 54,900 & 0,49197 & 0,91382 & 2,11 \\
\hline 6,5 & 0,146 & 0,17997 & 0,7382 & 36,12 & 6,771 & 0,8008 & 53,350 & 0,48286 & 0,91522 & 2,07 \\
\hline 6,9 & 0,134 & 0,16993 & 0,7560 & 35,31 & 6,620 & 0,7828 & 51,340 & 0,47200 & 0,91468 & 2.02 \\
\hline 5,5 & 0,123 & 0,16067 & 0,7729 & 34,23 & 6,418 & 0,7589 & 49,235 & 0,46167 & 0,91874 & 7,99 \\
\hline 5,6 & 0,112 & 0,15132 & 0,7904 & 33,04 & 6,195 & 0,7326 & 47,000 & 0,45174 & 0,92472 & $\frac{1}{3}, 96$ \\
\hline 4.5 & 0,101 & 0,14185 & 0,8086 & 31,72 & 5,948 & 0,7033 & 44,630 & 0,44222 & 0,93306 & 1,93 \\
\hline 4.9 & 0,090 & 0,1322 & 0,8273 & 30,26 & 5,673 & 0,6708 & 42,100 & 0,43309 & 0,94455 & 7,92 \\
\hline 3.5 & 0,078 & 0,12138 & 0,8483 & 28,84 & 5,406 & 0,6393 & 39,400 & 0.42439 & 0,95551 & 1,90 \\
\hline 3,6 & 0,067 & 0,11109 & 0,8682 & 27,01 & 5,063 & 0,5987 & 36,460 & 0,41598 & 0,97597 & 3,90 \\
\hline 2,5 & 0,056 & 0,10031 & 0,8886 & 24,92 & 4,673 & 0,5526 & 40,440 & 0,42762 & 1,00420 & 2,01 \\
\hline 2,0 & 0,045 & 0,08883 & 0,9095 & 22,51 & 4,221 & 0,4992 & 30,112 & 0,40110 & 1,04432 & 1,96 \\
\hline 1,5 & 0,034 & 0,07629 & 0,9309 & 19,66 & 3,686 & 0,4359 & 26,100 & 0,39367 & 1.10460 & 2,04 \\
\hline 1,0 & 0,022 & 0,06057 & 0,9546 & 16,51 & 3,095 & 0,3660 & 21,470 & 0,38672 & 1,19038 & 2,16 \\
\hline 0.5 & 0,011 & 0,04233 & 0,9772 & 11,81 & 2,215 & 0,2619 & 15,070 & 0,37964 & 1,39097 & $\frac{2}{3}, 48$ \\
\hline
\end{tabular}

\section{c. Pemilihan periode ulang}

Pemilihan periode ulang berdasarkan pada tingkat kerusakan yang ditimbulkan gelombang. Tingkat keruskan yang diizinkan berkisar antara $0-30 \%$. Kerusakan ini dapat dilihat apabila di daerah pantai tersebut terdapat bangunan pantai. Pada perencanaan ini diizinkan tingkat kerusakan $5-10 \%$ maka didapat tinggi gelombang dari arah Barat pada periode 25 tahunan adalah sebesar 2,00 m. Perhitungan tingkat kerusakan dapat dilihat pada Tabel 4.6.Tabel 4.6 Tinggi gelombang koefisien kerusakan arah Barat (25 tahun)

\begin{tabular}{|c|c|c|c|c|c|}
\hline $\begin{array}{c}\text { Tingkat } \\
\text { kerusakan }\end{array}$ & $(0-5) \%$ & $(5-10) \%$ & $(10-15) \%$ & $(15-20) \%$ & $(20-30) \%$ \\
\hline $\mathrm{H} / \mathrm{H}_{\mathrm{D}=0}$ & 1,00 & 1,08 & 1,19 & 1,27 & 1,37 \\
\hline $\mathrm{H}(\mathrm{m})$ & 2,16 & 2,00 & 1,81 & 1,70 & 1,58 \\
\hline
\end{tabular}

Pemilihan tinggi gelombang koefisien kerusakan arah Barat dikarenakan tinggi gelombang arah Barat lebih besar dari pada arah Barat Daya dan arah Selatan. Untuk pemilihan tinggi gelombang koefisien kerusakan diizinkan tingkat kerusakan (5-10) \%,

\subsubsection{Analisis Sedimentasi}

Angkutan sedimen sepanjang pantai ditimbulkan oleh arus sepanjang pantai yang dibangkitkan oleh gelombang pecah. Angkutan sedimen ini terjadi di surf zone yang erat hubungannya dengan arah datangnya gelombang dan arah angin dominan. Angkutan sedimen sepanjang pantai menyebabkan pendangkalan alur pada muara sungai.Besaran sedimen sepanjang pantai yang terjadi pada arah barat dapat dilihat pada rekapitulasi sedimentasi Tabel 4.7. Perhitungan selengkapnya analisis sedimentasi sepanjang pantai dapat dilihat pada perhitungan berikut :.

Tabel 4.7 Rekapitulasi Sedimentasi

\begin{tabular}{|c|c|c|c|c|c|c|c|c|c|c|}
\hline Arah & $\begin{array}{c}P \\
(K y / m 3)\end{array}$ & $\underset{\text { (In)/dlk2) }}{g}$ & $\begin{array}{l}\mathrm{Hb} \\
\text { (III) }\end{array}$ & $\begin{array}{l}\mathrm{db} \\
\text { (III) }\end{array}$ & $\begin{array}{c}\mathrm{Cb} \\
\text { (In/dlk) }\end{array}$ & $\begin{array}{c}\alpha \\
\left({ }^{\prime}\right)\end{array}$ & $\operatorname{SIN} \alpha$ & $\cos \alpha$ & $\begin{array}{c}\mathrm{PI} \\
(\mathrm{K} / \mathrm{m} / \mathrm{dl})\end{array}$ & $\begin{array}{c}\text { Qs } \\
\text { (In3/thu) }\end{array}$ \\
\hline$B$ & 1030 & 9,81 & 3,012 & 3,891 & 6,178 & 21,470 & 0,366 & 0,931 & 24117,079 & 31111031,73 \\
\hline $\mathrm{BD}$ & 1030 & 9.81 & 3.009 & 3.883 & 6.172 & 21.300 & 0.363 & 0,932 & 23881,415 & 30807024,85 \\
\hline$S$ & 1030 & 9,81 & 1,911 & 2,130 & 1,882 & 19,920 & 0,311 & 0,910 & 7211,005 & 9302196,47 \\
\hline \multicolumn{10}{|c|}{ Rata-rata anykutan sedinen sepanjany pantai } & $23.740 .084,35$ \\
\hline
\end{tabular}

\subsubsection{Perhitungan Konstruksi Jetty}

\section{A. Kedalaman alur muara sungai}

Penentuan kedalaman minimum alur muara sungai ditinjau dari ukuran kapal terbesar yang melewati alur muara tersebut, hal ini dikarenakan alur yang direncanakan memiliki potensi lalu lintas pelayaran. Besarnya kedalaman minimum alur pelayaran Muara Batu Putih adalah 2,50 m. Sedangkan kedalaman alur normal Muara Batu Putih adalah $1 \mathrm{~m}$, nilai tersebut tidak memenuhi syarat minimum alur pelayaran maka 
harus dilakukan pengerukan agar memenuhi kedalaman alur pelayaran minimum. Perhitungan kedalaman alur muara minimum dapat dilihat sebagai berikut :

\section{Perhitungan Kedalaman Alur Pelayaran}

Data dimensi kapal tipe 30 GT adalah :

$\begin{array}{ll}\text { Panjang (L) } & =25 \text { meter, } \\ \text { Lebar (B) } & =5 \text { meter,dan } \\ \text { Draft (df) } & =1,5 \text { meter. }\end{array}$

Perhitungan kedalaman alur minimum muara :

$\mathrm{dn} \quad=1,5 \mathrm{df}=1,5 \times 1,5$ meter $=2,25$ meter

$\mathrm{EL}_{\text {bed }}=\mathrm{LLWL}-\mathrm{dn}=0,00-2,25$ meter $=2,25$

$\approx 2,5$ meter

Maka, kedalaman alur minimum adalah 2,5meter.Karena kedalaman alur rata-rata lebih kecil dari kedalaman alur minimum, maka dilakukan pengerukan dibeberapa titik alur pelayaran.

\section{B. Lebar alur muara sungai}

Lebar alur muara sungai dapat ditentukan dengan lebar sungai atau pun lebar minimum persyaratan standar untuk lalu lintas kapal nelayan yang menggunakan alur tersebut. Pada perencanaa ini akan digunakan lebar hidraulik sungai yang lebarnya $80 \mathrm{~m}$ sebagai alur desain dikarenakanlebar hidraulik sungai lebih besar dari lebar alur minimum persyaratan standar lalu lintas kapal.

\section{Perhitungan Lebar Alur Pelayaran}

Lebar alur di lokasi rencana adalah 80 meter. Alur minimum pelayaran dihitung atas lebar alur minimum untuk lalu lintas satu jalur dan lebar alur minimum untuk dua jalur.

a. Lebar alur minimum lalu lintas satu jalur

$$
\left(\mathrm{W}_{\mathrm{n}} \geq 4,8 \mathrm{~B}\right)
$$

$\mathrm{W}_{\mathrm{n}}=4,8 \mathrm{~B}=4,8 \times 5$ meter $=24$ meter.

b. Lebar alur minimum lalu lintas dua jalur

$\left(\mathrm{W}_{\mathrm{n}} \geq 7,6 \mathrm{~B}\right)$

$\mathrm{W}_{\mathrm{n}}=7,6 \mathrm{~B}=7,6 \times 5$ meter $=38$ meter.

\section{Panjang jetty}

Pemilihan panjang jetty didasarkan pada perbandingan besarnya sedimentasi sepanjang pantai dan sedimen dari sungai. Pada kondisi muara ini sedimendari sungai sangat kecil maka sedimen sungai diasumsikan 0. Karena sedimen sepanjang pantai lebih besar maka direncanakan konstruksi jetty panjang. Penetapan ujung jetty dilakukan berdasarkan lokasi kedalaman gelombang pecah yaitu $3 \mathrm{~m}$, dengan panjang jetty sebelah kanan adalah $450 \mathrm{~m}$ dan panjang jetty sebelah kiri $460 \mathrm{~m}$.

\section{Elevasi puncak jetty}

Elevasi puncak jetty ditentukan berdasarkan tinggi run-up gelombang dan tinggi kebebasan, tinggi kebebasan yang umumnya digunakan pada perencanaan jetty adalah $0,5 \mathrm{~m}$. Tinggi run-up gelombang dihitung pada lokasi perencanaan, besarnya run-up juga dipengaruhi oleh jenis material yang digunakan. Pada perencanaan ini material yang digunakan adalah batu alam, sehingga tinggi run-up yang didapat adalah 3,60 m. Tinggi jetty di setiap kedalaman dapat dilihat pada Tabel 4.8.

Tabel 4.8 Elevasi puncak jetty

\begin{tabular}{|c|c|c|}
\hline \multirow{2}{*}{$\begin{array}{c}\text { d } \\
\text { m) }\end{array}$} & \multicolumn{2}{|c|}{ Batu Pecah } \\
\cline { 2 - 3 }$(\mathbf{m}, 0$ & $+3,60$ & ds Jetty (m) \\
\hline 1,5 & $+3,60$ & 4,6 \\
\hline 2,0 & $+3,60$ & 5,1 \\
\hline 2,5 & $+3,60$ & 5,6 \\
\hline 3,0 & $+3,60$ & 6,1 \\
\hline
\end{tabular}


Kedalaman (d) didapat dari peta topografi dan bathymatri dan pemilihan kedalaman berdasarkan kedalaman minimum $1 \mathrm{~m}$ dan kedalaman gelombang pecah $3 \mathrm{~m}$. Dari hasil perhitungan didapat elevasi puncak jetty adalah $3,60 \mathrm{~m}$. Tinggi jetty di setiap kedalaman inilah yang akan dijadikan sebuah perencanaan desain jetty.

\section{E. Lebar puncak jetty}

Pada penentuan lebar puncak jetty faktor mobilisasi peralatan berat dan jumlah unit batu yang digunakan pada setiap bagian banggunan menjadi acuan desain. Dari hasil perhitungan didapat lebar puncak jetty adalah 3,00 m pada bagian lengan dan 4,50 m pada bagian kepala. Tabel 4.9 Lebar Puncak Jetty.

Tabel 4.9 Lebar Puncak Jetty

\begin{tabular}{|c|c|c|c|c|c|c|c|}
\hline Batu Pecah & $\mathbf{N}$ & $\mathbf{K}_{\Delta}$ & $\begin{array}{c}\mathbf{W} \\
(\text { ton/u) }\end{array}$ & $\begin{array}{c}\mathbf{V} r \\
(\text { ton/m3) }\end{array}$ & $\begin{array}{c}\mathbf{B} \\
(\mathbf{m})\end{array}$ & $\begin{array}{c}\mathbf{B} \text { desain } \\
(\mathbf{m})\end{array}$ \\
\hline Kepala & 4 & 1,15 & 1,429 & 2,65 & 4,68 & 4,50 \\
\hline Lengan & 3 & 1,15 & 1,357 & 2,65 & 2,76 & 3,00 \\
\hline
\end{tabular}

\section{F. Tebal dan jumlah butir batu lapis pelindung}

Pada perhitungan tebal lapis pelindung didasarkan pada berat dan ukuran butir batu yang digunakan pada setiap bagian jetty. Perhitungan jumlah butir batu lapis lindung dihitung dengan setiap luasan $10 \mathrm{~m}^{2}$. Perhitungan lebih lanjut dapat dilihat pada dibawah dan Tabel 4.10dan Tabel 4.11.

Tabel 4.10 Tebal Lapis Pelindung Jetty

\begin{tabular}{|c|c|c|c|c|c|c|}
\hline \multirow{2}{*}{ Lapis } & \multicolumn{6}{|c|}{ Kepala } \\
\hline & $\mathbf{n}$ & $\mathbf{K}_{\Delta}$ & $w$ (ton) & $\operatorname{Vr}\left(\operatorname{ton} / \mathrm{m}^{3}\right)$ & $t(m)$ & troesan (m) \\
\hline$t_{1}$ & 2 & 1,15 & 1,429 & 2,65 & 1,87 & 2,00 \\
\hline$t_{2}$ & 2 & 1,15 & 0,143 & 2,65 & 0,87 & 1,00 \\
\hline \multirow{2}{*}{ Lapis } & \multicolumn{6}{|c|}{ Lengan } \\
\hline & $\mathbf{n}$ & $K_{\Delta}$ & W (ton) & $\operatorname{Vr}\left(\operatorname{ton} / \mathrm{m}^{3}\right)$ & $t(m)$ & tdesain (m) \\
\hline$t_{1}$ & 2 & 1,15 & 1,357 & 2,65 & 1,87 & 2,00 \\
\hline$t_{2}$ & 2 & 1,15 & 0,138 & 2,65 & 0,85 & 1,00 \\
\hline
\end{tabular}

Tabel 4.11 Jumlah Batu Pelindung Jetty

\begin{tabular}{|c|c|c|c|c|c|c|c|}
\hline \multirow[b]{2}{*}{ Lapis } & \multicolumn{7}{|c|}{ Kepala } \\
\hline & $\underset{\left(m^{2}\right)}{A}$ & $\mathbf{n}$ & $K_{\Delta}$ & $(\%)$ & $\begin{array}{c}\text { W } \\
(\operatorname{ton} / u)\end{array}$ & $\begin{array}{c}\mathrm{Vr} \\
(\operatorname{ton} / \mathrm{m} 3)\end{array}$ & $\frac{N}{\text { (unit) }}$ \\
\hline$N_{t}$ & 10 & 2 & 1,15 & 37 & 1,429 & 2,65 & 22 \\
\hline$N_{2}$ & 10 & $\overline{2}$ & 1,15 & 37 & 0,143 & 2,65 & 102 \\
\hline$N_{3}$ & 10 & 2 & 1,15 & 37 & 0,007 & 2,65 & 748 \\
\hline \multirow[b]{2}{*}{ Lapis } & \multicolumn{7}{|c|}{ Lengan } \\
\hline & $\stackrel{A}{\left(m^{2}\right)}$ & $\mathbf{n}$ & $k \Delta$ & $\begin{array}{c}P \\
(\%)\end{array}$ & $\begin{array}{c}W \\
\text { (ton/u) }\end{array}$ & $\begin{array}{c}\mathrm{Vr} \\
(\text { ton/ms) }\end{array}$ & $\begin{array}{c}N \\
\text { (unit) }\end{array}$ \\
\hline $\mathrm{N}_{1}$ & 10 & 2 & 1,15 & 37 & 1,357 & 2,65 & 23 \\
\hline$N_{2}$ & 10 & 2 & 1,15 & 37 & 0,136 & 2,65 & 105 \\
\hline$N_{3}$ & 10 & 2 & 1,15 & 37 & 0,007 & 2,65 & 774 \\
\hline
\end{tabular}

\section{G. Stabilitas batu lapis}

Berat batu lapis mempunyai dua bagian yaitu bagian kepala dan lengan, dan setiap letak berat batu lapis tersebut masing-masing dibagi menjadi tiga lapis. Pada lapis pertama merupakan peletakan batu-batu besar dan batu-batu kecil diletakan pada lapis inti atau lapis ke tiga, hal ini merupakan hasil dari perhitungan stabilitas batu lapis. Hasil perhitungan dapat dilihat pada Tabel 4.12.

Tabel 4.12 Berat Batu Pelindung Jetty

\begin{tabular}{|c|c|c|c|c|c|c|c|c|c|c|}
\hline $\begin{array}{c}\mathrm{Vr} \\
\text { (ton/m3) }\end{array}$ & $\begin{array}{l}\mathrm{H}_{\mathrm{a}} \\
(\mathrm{m})\end{array}$ & $K_{D}$ & $\begin{array}{c}\mathrm{Vw} \\
\text { (ton/m3) }\end{array}$ & $\mathbf{S}_{\mathrm{r}}$ & $\stackrel{\text { Cot }}{\Theta}$ & $\begin{array}{c}W_{1} \\
(\mathrm{~kg} / \mathrm{u})\end{array}$ & $\begin{array}{c}W_{2} \\
(\mathrm{~kg} / \mathrm{u})\end{array}$ & $\begin{array}{c}W_{3} \\
(\mathrm{~kg} / \mathrm{u})\end{array}$ & \multicolumn{2}{|c|}{ Keterangan } \\
\hline 2,65 & 2,00 & 1,9 & 1,03 & 2,57 & 2 & 1428,580 & 142,858 & 7,143 & & Kepala \\
\hline 2,65 & 2,00 & 2 & 1,03 & 2,57 & 2 & 1357,151 & 135,715 & 6,786 & $\begin{array}{l}\text { Batul } \\
\text { Pecahn }\end{array}$ & Lengan \\
\hline
\end{tabular}




\section{H. Perlindungan kaki jetty}

Pelindung kaki jetty digunakan untuk menjaga stabilitas konstruksi jetty akibat gerusan gelombang. Pada perencanaan ini dimensi perlindung kaki jetty bagian lengan disamakan dengan dimensi kaki bagian kepala dikarenakan pembulatan dari hasil perhitungan. Tinggi pelindung kaki jetty adalah 2,00 $\mathrm{m}$ dan lebar adalah 3,00 m. Berat batu yang akan digunakan pada lapis pelindung kaki jetty adalah 3,00 t/unit. Perhitungan dapat dilihat sebagai berikut dan Tabel 4.13dan Tabel 4.14.

Tabel 4.13 Tinggi dan Lebar Kaki Pelindung Jetty

\begin{tabular}{|c|c|c|c|c|c|c|}
\hline \multirow[b]{2}{*}{ Dimension } & \multicolumn{6}{|c|}{ Isepala } \\
\hline & $\mathbf{n}$ & $\mathbf{K}$. & $\frac{\text { WV }}{(\operatorname{ton} / \mathrm{u})}$ & $\frac{\gamma=}{(\tan / \min 3)}$ & $\begin{array}{c}t \\
(\mathrm{~m})\end{array}$ & (ma) \\
\hline$x$ & 2 & 1,15 & 1,429 & 2,65 & 1,87 & 2,00 \\
\hline $\mathbf{B}$ & 3 & 1.15 & 1.429 & 2.65 & 2.81 & 3.00 \\
\hline \multirow[b]{2}{*}{ Dimensian } & \multicolumn{6}{|c|}{ Lengan } \\
\hline & $\mathbf{n}$ & Is. & $\begin{array}{c}\text { WV } \\
(\operatorname{ton} / u)\end{array}$ & $\begin{array}{c}\gamma= \\
(\operatorname{ton} / \mathrm{m} 3)\end{array}$ & $(\mathrm{m})$ & $\begin{array}{c}\text { t dessin } \\
\text { (ma) }\end{array}$ \\
\hline I & $z$ & 1,15 & 1,357 & 2,05 & 1,84 & 2,00 \\
\hline I 3 & 3 & 1,15 & 1,357 & 2,65 & 2,76 & 3,00 \\
\hline
\end{tabular}

Tabel 4.14 Berat Batu Kaki Pelindung Jetty

\begin{tabular}{|c|c|c|c|c|c|c|c|c|c|c|}
\hline $\begin{array}{l}d_{5} \\
(m)\end{array}$ & $\begin{array}{l}d_{b} \\
(\mathbf{m})\end{array}$ & $d_{b} / d_{s}$ & $\mathbf{N}_{5}{ }^{3}$ & $\begin{array}{c}\gamma_{x} \\
(\operatorname{ton} / m 3)\end{array}$ & $\begin{array}{c}\gamma_{w} \\
(\operatorname{ton} / \mathrm{m} 3)\end{array}$ & $\mathbf{S}_{\mathbf{r}}$ & $\begin{array}{c}\mathbf{H} \\
(\mathbf{m})\end{array}$ & $\begin{array}{c}\text { W } \\
(\operatorname{ton} / \mathbf{u})\end{array}$ & $\begin{array}{c}\mathbf{W} \\
\text { dessim } \\
(\text { ton } / \mathbf{u})\end{array}$ & Bag̣ian \\
\hline 5,10 & 3,10 & 0,61 & 19 & 2,65 & 1,03 & 2,57 & 2,00 & 0,29 & 3,00 & Lerigan \\
\hline 5,60 & 3,60 & 0,64 & 20 & 2,65 & 1,03 & 2,57 & 2,00 & 0,27 & 3,00 & Lerigan \\
\hline 6,10 & 4,10 & 0,67 & 21 & 2,65 & 1,03 & 2,57 & 2,00 & 0,26 & 3,00 & Lerigan \\
\hline 6,60 & 4,60 & 0,70 & 22 & 2,65 & 1,03 & 2,57 & 2,00 & 0,25 & 3,00 & Kebala \\
\hline 7,10 & 5,10 & 0,72 & 23 & 2,65 & 1,03 & 2,57 & 2,00 & 0,24 & 3,00 & Keopala \\
\hline
\end{tabular}

\subsection{Pembahasan}

Pada bagian ini dikemukakan pembahasan mengenai analisis dan hasil perhitungan yang berhubungan dengan studi. Hal-hal yang dibahas mencakup tinggigelombang rencana dan analisis sedimentasi konstruksi jetty.

\subsubsection{Pemilihan periode ulang}

Dengan menggunakan data angin pencataan di darat yang di peroleh dari stasiun Meteorologi Cut Nyak Dhien Nagan Raya Perhitungan tinggi gelombang rencana dapat dilakukan dengan mengalih ragamkan data angin di darat menjadi data angin di laut dan dihitungan berdasarkan periode ulang $2,5,10$, 25, 50 dan 100 tahunan. Dari hasil perhitungan didapat tinggi gelombang dengan periode ulang 25 tahunan sebesar2,00 m,dan kedalaman gelombang pecah sedalam $-3 \mathrm{~m}$.

\subsubsection{Analisis sedimentasi}

Angkutan sedimen sepanjang pantai dihitung dengan rumus CERC yang dihitung berdasarkan komponen fluks energi gelombang. Pada analisis ini angkutan sedimen dihitung dari tiga arah mata angin yaitu Barat, Barat Daya dan Selatan yang dihitung dalam satu tahun. Pada Tabel 4.8 dari perhitunganketiga arah tersebut di dapatlah pergerakan total sedimen sebesar $23.740 .084,35 \mathrm{~m}^{3} /$ tahun yang bergerak ke arah Barat Laut.

\subsubsection{Konstruksi jetty}

Mengurangi pendangkalan pada jetty sebelumnya di Muara Batu Putih, maka direncanakan ulang konstruksi jetty. Hal ini dikarenakan sesuai dengan fungsinya yaitu untuk menghalangi penumpukan sedimen sepanjang pantai di mulut muara yang mengakibatkan pendangkalan alur muara.

Konstruksi jetty yang direncanakan adalah tipe jetty panjang. pemilihan tipe jetty ini karena sedimen sepanjang pantai lebih dominan dari sedimen dari sungai. Peletakkan jetty dimulai pada kedua sisi muara untuk pangkal jetty dan ujung jetty diletakkan diluar gelombang pecah yaitu pada kedalaman -3 m. Panjang jetty sebelah kanan adalah $450 \mathrm{~m}$ dan sebelah kiri $460 \mathrm{~m}$. 
Konstruksi jetty dibangun dari batu alam. Mateial ini dipilih karena lebih mudah di dapatkan dan mudah dalam perbaikan. Penetapan lebar alur mengikuti lebar hidraulik sungai sebesar $80 \mathrm{~m}$, hal ini dikerenakan lebar hidraulik sungai lebih besar dari lebar alur syarat minimum. Kedalaman alur harus dilakukan pengerukan dikerenakan kedalaman alur sungai semula hanya memiliki kedalaman $1 \mathrm{~m}$, sehingga diperlukan pengerukan minimum sedalam 2,5 m. Pengerukan yang dilakukan dapat menyebabkan lonsor pada tanah sehingga pelindung kaki jetty di buat lebih dalam.

Elevasi jetty berdasarkan HHWL (highest high water level), tinggi gelombang rencana dan run-up gelombang, maka didapat ketinggian $+3,60 \mathrm{~m}$. Dari hasil perhitungan didapat tebal lapis pertama 2,00 $\mathrm{m}$ dan tebal lapis kedua 1,00 m untuk bagian kepala dan lapis pertama 2,00 m dan tebal lapis kedua 1,00 m untuk bagian lengan lengan. Talud yang digunakan $1: 2$ pada sisi laut dengan anggapan dapat mengurangi limpasan gelombang. Pada sisi pelayaran digunakan talud $1: 1$.

Lebar puncak jetty untuk bagian kepala adalah 4,50 $\mathrm{m}$ dan bagian lengan 3,00 $\mathrm{m}$. Untuk menjaga stabilitas konstruksi jetty digunakan butir batu pelindung dengan berat 1,429 ton/unituntuk bagian kepala dan 1,357 ton/unit untuk bagian lengan. Untuk setiap luasan $10 \mathrm{~m}^{2}$ bagian kepala jumlah butir pelindung lapis pertama adalah 22 unit, lapis kedua adalah 102 unit dan untuk lapis ketiga 748 unit. Untuk bagian lengan 23 unitdi lapis pertama 105 unit di lapis kedua dan 774 unit untuk lapis ketiga.

Untuk mencegah gerusan oleh gelombang pada dasar bangunan maka direncanakan pelidung kaki dari material batu alam, dengan berat butir 3,00 t/unit, tinggi 2,00 m dan lebar 3,00 m. Pada bagian alur pelayaran pelindung kaki ini mempunyai tinggi desain yang lebih besar karena adanya pengerukan pada alur pelayaran. Dari langkah - langkah perhitungan diatas, dimensi konstruksi jetty disajikan dalam bentuk gambar desain jetty. Desain jetty dapat dilihat sebagai berikut :

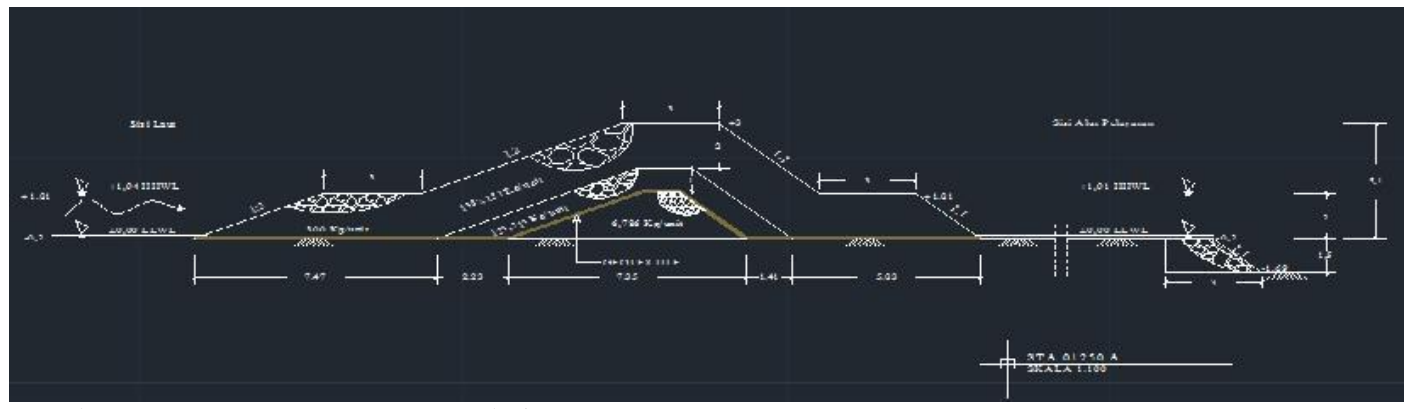

Gambar 4.6 : Potongan Konstruksi Jetty STA 0+250

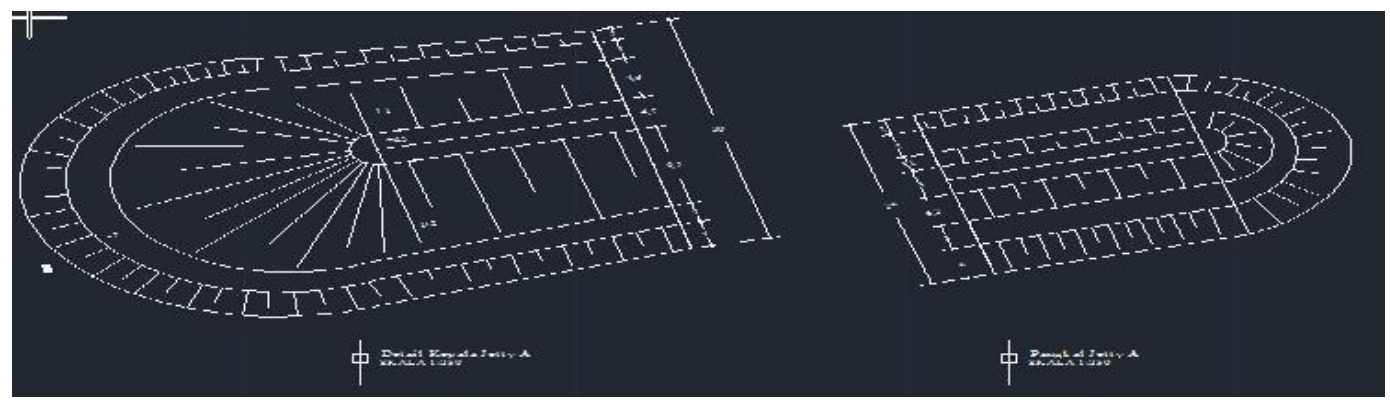

Gambar 4.7 : Detai Kepala dan Pangkal Jetty

\section{KESIMPULAN DAN SARAN}

Kesimpulan diambil berdasarkan hasil perhitungan hasil dan pembahasan. Saran diberikan untuk kualitas perencanaan yang lebih baik di masa mendatang.

\section{$5.1 \quad$ Kesimpulan}

Kesimpulan yang dapat diambil dari perencanaan ulang yang telah dilakukan adalah:

1. Rekapitulasi angkutan sedimen didominasi oleh angkutan sedimen sepanjang pantai yaitu sebesar 23.740.084,35 $\mathrm{m}^{3} /$ tahun menuju ke arah Barat Laut.Besarnya nilai sedimentasi dikarenakan lokasi penelitian langsung berhadapan dengan laut lepas yaitu arah barat. Dengan besarnya nilai angkutan 
sedimen, kesimpulan ini menunjukan sangat cocok apabila konstruksi jetty memakai tipe jetty panjang dari pada konstruksi tipe jetty pendek sebelumnya.

2. Konfigurasi ulang struktur Konstruksi pelindung muara yang direncanakan adalah jetty tipe panjang dengan material penyusunnya batu gunung yang terdiri dari tiga lapis, yaitu lapisan terluar, lapisan kedua, dan lapisan inti. Pada lapis terluar bagian kepala jetty berat batu berkisar antara 1428,580 $\mathrm{kg} / \mathrm{unit}$ dan bagian lengan jetty $1357,151 \mathrm{~kg} / \mathrm{unit}$. Pada lapis kedua bagian kepala jetty berkisar antara $142,858 \mathrm{~kg} / \mathrm{unit}$ dan bagian lengan jetty $135,715 \mathrm{~kg} / \mathrm{unit}$. Untuk lapis inti bagian kepala jetty adalah 7,143 kg/unit dengan bagian lengan jetty6,786 kg/unit. Panjang konstruksi jetty dari perencanaan ulang adalah sebelah kiri lebih panjang yaitu $460 \mathrm{~m}$ dari pada konstruksi jetty sebelah kanan yaitu $450 \mathrm{~m}$ dengan kedalam battimatri $3 \mathrm{~m}$.

\subsection{Saran}

1. Diharapkan dari penelitian ini dapat menjadi solusi masalah yang terjadi dilokasi Muara Batu Putih.

2. Untuk menanggulangi masalah erosi yang terjadi akibat pembangunan jetty dapat dipertimbangkanan untuk melakukan pembangunan revetment di sebelah kananjetty.

3. Diharapkan dari segi perencanaan bangunan pengaman pantai pada pelaksanaan dilapangan untuk memperhatikan dampak lingkungan sekitar pantai.

4. Diharapkan pada penelitian ini dapat bermanfaat untuk penelitian lanjutan yang berkaitan dengan bangunan pengaman pantai yang akan datang di Universitas Teuku Umar.

\section{DAFTAR KEPUSTAKAAN}

Asnawi., 2010. Perencanaan Bangunan Pengaman Pantai di Bulu Tuban,http://digilib.its.ac.id/public/ITSpaper-28138-3108100703-Paper.pdf. April 2015 Fakultas Teknik Jurusan Teknik Sipil FTSPITS.

CERC, 1984. Shore Protection Manual, Volume II, US Army Coastal Engineering Research Center, Washington.

Fahmi, M., 2013. Perencanaan Jetty di Muara Lambada Lhok Kabupaten Aceh Besar, Skripsi,Fakultas Teknik Universitas Syaih Kuala, Banda Aceh.

Google Map 2014, kabupaten Aceh Barat, viewed maret 2015, available from internet.http://www.leuserfoundation.org/index.php.Maret 2015

Google Search2013, bangunan pengaman pantai, viewed April 2015, available frominternet.http://www.ilmusipil.com.April 2015

Pataton, K.Y., 2013. Perencanaan Jetty di Muara Sungai Ranoyapo Amurang,http://download.portalgaruda.org/article.php?article=108097\&val=1013-8. April 2015 Fakultas Teknik Jurusan Teknik Sipil Universitas Sam Ratulagi.

Pratikto, dkk., (2000). Perencanaan Fasilitas Pantai dan Laut http:// digilib.its.ac.id/public/ITSUndergraduate-17492-Bibliography.pdf, BPFE, Yogyakarta.

Syamsudin, N. Yuwono, dan R. M. Azhar, 2005. Pedoman Perencanaan Jeti Tipe Rubble Mound untuk Penanggulangan Penutupan Muara Sungai oleh Sedimen, Badan Litbang PU Departemen Pekerjaan Umum, Jakarta.

Triatmodjo, B., 2012. Perencanaan Bangunan Pantai, Beta Offset, Yogyakarta.

Triatmodjo, B., 1999. Teknik Pantai, Beta Offset, Yogyakarta. 